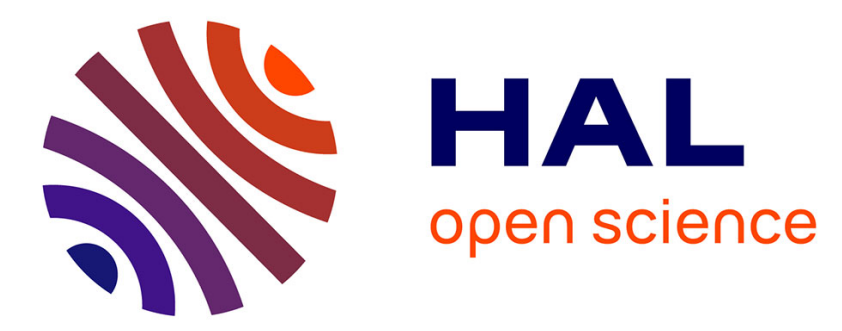

\title{
Monte Carlo simulation on the step coverage formation processes in chemical vapor deposition
}

\author{
Y. Shimogaki, T. Uchida, S. Shiga, Y. Egashira, H. Komiyama
}

\section{To cite this version:}

Y. Shimogaki, T. Uchida, S. Shiga, Y. Egashira, H. Komiyama. Monte Carlo simulation on the step coverage formation processes in chemical vapor deposition. Journal de Physique IV Proceedings, 1993, 03 (C3), pp.C3-203-C3-203. 10.1051/jp4:1993326 . jpa-00251383

\section{HAL Id: jpa-00251383 https://hal.science/jpa-00251383}

Submitted on 1 Jan 1993

HAL is a multi-disciplinary open access archive for the deposit and dissemination of scientific research documents, whether they are published or not. The documents may come from teaching and research institutions in France or abroad, or from public or private research centers.
L'archive ouverte pluridisciplinaire HAL, est destinée au dépôt et à la diffusion de documents scientifiques de niveau recherche, publiés ou non, émanant des établissements d'enseignement et de recherche français ou étrangers, des laboratoires publics ou privés. 


\title{
Monte Carlo simulation on the step coverage formation processes in chemical vapor deposition
}

\author{
Y. SHIMOGAKI, T. UCHIDA, S. SHIGA, Y. EGASHIRA and H. KOMIYAMA \\ Department of Chemical Engineering, The University of Tokyo, 7-3-1 Hongo, Bunkyo-ku, Tokyo 113, \\ Japan
}

The device fabrication process normally requires uniform film thickness profile for every chemical vapor deposition system, but the high aspect ratio of sub-micron device inhibits the conformal deposition within the trenches or via holes and it is now an important issue in ULSI fabrication. As the step coverage profile is basically governed by the reactivity and diffusivity of depositing species, some important aspects of CVD process, like as the sticking probability, surface diffusion, the contribution of reactive intermediate species can be evaluated by examining the deposition profile in the micron sized trenches.

In the present paper, direct Monte Carlo simulation program was developed to analyze the step coverage formation process. The simulation program uses mesh model to describe the trench profile. It arranges the active field which is a sectional area of trench with $200 \times 450$ resolution. This field has periodic boundary condition for horizontal directions. First, a particle is generated above the trench profile and its $x$ coordinate is random. The generated particle has random velocity which obeys cosine low. This particle flies in the field until it flies for the length which is calculated from the mean free path (it means collision) or it reaches the trench surface. When it collides with other particles, its velocity is elastically changed at random. When it reaches the trench surface, it reflects or absorbs according to the sticking probability. The absorbed particle is moved to other position on the surface due to the surface diffusion, and reflected particle gets new velocity which again obeys cosine low.

This simulation program was used to evaluate the sticking probabilities of some CVD systems. Several attempts were made to clarify the effect of surface diffusion on the step coverage and it was demonstrated that surface diffusion does not make a serious effect on the step coverage profile if the mean diffusion length is smaller than the trench dimensions. It was also shown that the contribution of the surface diffusion can be evaluated by comparing the step coverage profile within the trenches with same aspect ratio and different size. The smaller trench will show more conformal step coverage with same surface diffsuion length.

The highly reactive intermediate species formed by the gas phase reactions also affect the step coverage profile. If the highly reactive intermediate species, with the sticking probability of nearly unity, contribute to the film growth, the step coverage profile will be significantly deteriorated. Under these conditions, the contribution of the intermediate species to the total film growth rate is the major factor in controlling the step coverage profile. This contribution ratio cannot be estimated from the step coverage profile, but the simulated results suggested that there is a possibility to clarify the existence of intermediate species by observing the step coverage profile within a trench with high aspect ratio of more than 10 .

The capillary condensation phenomenon was also taken into account in the simulation program to evaluate the step coverage of $\mathrm{SiO}_{2}$ films deposited from $\mathrm{TEOS} / \mathrm{SiH}_{4} / \mathrm{O}_{2}$, where flowshaped step coverage can be observed in narrow trenches. It was suggested that some surface fluid should contribute to the film growth in this reaction system. 